\title{
Civic Competence as a Target Component of Education Content
}

\author{
Gayane Poghosyan ${ }^{1}$, Anahit Gasparyan² \\ ${ }^{1}$ PhD, Head of the UNESCO Chair on "Education for Sustainable Development" at the Center for Ecological- \\ Noospheric Studies of the National Academy of Sciences of Armenia, RA \\ ${ }^{2} \mathrm{PhD}$, Chief Specialist of the National Institute of Education of the Ministry of Education and Science, RA \\ gayane_surenovna@yahoo.com,anahit-movsesi@mail.ru
}

\begin{abstract}
Nowadays it is a necessity to include the competence to the target component of education content.An individual and socially significant activity of real-world objects should be interconnected with the other target components of content and based on experience as a social requirement/Khutorskoy A.V, 2013. Civic competence is represented as: the unity of civil competence of the subject (Zimnyaya I.A.,2006), the unity of readiness and abilities, which allows the active, effective and responsible control of the rights and duties of a member of a democratic society, applying the knowledge and skills and civic qualities.The issue of development of civil competence was always faced teachers almost in all countries and was considered only as a pedagogical activity, and not as the educational problem.For the formation of civic competence, it is necessary first of all to form the abilities of both students and teachers who can make decisions in different living conditions - in different training situations (self-education) they can make decisions, identify problems and give solutions, as well as purposeful and responsible actions, at the same time developing creative and critical thinking.
\end{abstract}

Keywords: competence; civic competence; target component of education content; civic qualities; ethnoculture

\section{Introduction}

According to the definitions of educational competence made by the Council of Europe, it is the ability and readiness to learn during all the life. Competence requires the source of knowledge to:

- Promote the establishment and development of research, communication and collaborative abilities for students.

- Orient the students to the public useful activity field (to have oral and written communication skills), that will prevent a person from social isolation/A European Reference Framework, 2006.

Education is one of the human rights. It is also a precondition for sustainable development, an essential tool for the formation of a competent citizen, effective governance, decision-making, and the development of democracy, and it contributes to:

- Changing people's attitudes, enabling them to make the world safer, thereby raising the quality of life,

- Development of critical thinking,

- Knowledge acquisition,

- Formation of skills, abilities and values

In order to include the competence component into the education content it is needed:

- To reformulate the objectives of the education content

- Develop teaching methods and educational technologies that will help master the content;

- Develop appropriate assessment system

- Prepare and train pedagogical cadres/Galoyan S., 2004 
All these will give the opportunity:

- To identify the peculiarities of human life experience, in the case of joining various social groups,

- To carry out an assessment of own vital forces in the conditions of joint lifestyle with people who have other ethnocultural traditions.

If in Soviet years the ideological component was emphasized in civic education, in the post-Soviet period, along with the increased importance of civic education (as a necessary condition for the survival of states), various interesting approaches to solving the problem arise. At the same time, civic competence acts as an integral competence based on a number of core competencies.

For some time the formation of civil competency was related to the teaching of concrete subjects. According to a number of researchers, while studying history and social sciences, students make an idea of the difference between the concept of spiritual development, the concept of "equality of rights" and "equity". The subject of literature provides an extra opportunity to detail and clarify such important concepts as "moralizing", "right", "legality", "responsibility", "dignity", "honor".

Learners were asked to pay attention to ethical-philosophical types of questions - good and evil, life and death, change of generations, human and God, human and nature, human and nation, honor and duty, conscience, moral choice.

When learning foreign languages, students get general information about the country, the language that they study, about the country's national culture and its contribution to world culture, which contributes to mutual understanding between peoples and society and their tolerance. The subjects of the natural sciences (biology, natural science, ecology, geography and healthy lifestyle) focus on the natural, social and economic problems of human rights, as well as on studying the laws of nature, the misuse of which can lead to disastrous consequences. Natural science objects form a sense of responsibility towards the world, both locally and globally.

\section{Research Methods}

According to a number of researchers, the effectiveness of the formation of students' civic competence depends not on the content of the subject, but on the correct method chosen for training and education. Such methods include persuasion and explanation, a positive example (demonstration of positive behavior), problematic situations and ways to success, analysis of differences of opinion, democratic dialogue and competition, pedagogical management, projects, role-playing games, leadership management and reputation building, methods of joint creative work and national pedagogical means.

For the formation of civic self-awareness in the field of civic competence, Russian and French educators particularly emphasize the method of writing "social biographies" (or personal research). This method enables to study the subjective aspects of social life. He fixes the personal attitude of a person to those social processes and socio-psychological situations in which he was involved, indirectly or directly. One of the types of these methods, technology, is an interview without a certain aim, the testimony of relatives, various correspondence, photographs, autobiographical episodes, recordings of their own life (about certain stages of their own life or family life, or about family life of one of the relatives). All these biographical 
methods make it possible to detect the features of different social experiences at different depths.

In American pedagogy, methods of forming civic competence are usually divided into methods of civic consciousness and the formation of civic skills. They distinguish between two groups of citizen competence: the first is informational debates (lectures, conversations, discussions, problem assignments, video viewing and the use of computer technology). And the second group is the methods of independent perception of the material (the performance of tasks by studying textbooks, monographs, biographies, autobiographies, stories and epics).

Methods designed to build civil rights are aimed at the development of intellectual (through the method of debate, brainstorming, dramatization, analysis of political information, organization of international events and political games) and practical skills (opinion polls, work in charitable organizations, participation in juvenile proceedings, work on the creation of public projects and participation in the school management process).

The effectiveness of the formation of learners' civic competence does not depend on the content of the subject, but on the method chosen for training and education and pedagogical technology (Gasparyan A.M., 2016, PoghosyanG.S., 2015, Abrahamyan N., 2014). These forms make it possible to reveal the peculiarities of a person's life experience, as well as the nature of mastering one's own life forces in a joint way of live together with other people.

At the heart of the problem of the perception of cultural heritage and the borrowing of cultures by children is the handling of issues of national and universal harmony.

\section{Discussion}

\subsection{Potential Opportunities of Ethnocultural Traditions}

According to the concept of modernizing education in different countries, the education system should form people who can live not only in civil society and in a state of law, but will also be fully prepared for the application of civil and political rights. At the same time, in the fund of accumulated knowledge about the phenomenon of "civic competence" there is a small amount of complex psychological and pedagogical research, which examines the possibilities of applying national-cultural traditions.

According to the studies of many local and regional philosophers, historians, culturologists and artists, the basis of the problem of perceiving cultural heritage and borrowing cultures by students is the development of issues of national and universal harmony. The rapprochement of the national culture with the new generation becomes a pedagogical problem of our time, since each nation not only preserves the traditions of historical education, but also tries to bring it to the next generations in order not to lose its national identity and peculiarity/Kulikova L., 2012.

A new educational paradigm, where priority is given to the formation of civic competence, provides the student with:

- Meaningful and responsible social activities

- Moral political position,

- Readiness to implement civil obligations as a full member of society.

The issue of cultural heritage perception and borrowing of cultures by children should be the subject of national and universal, international and regional harmony. The rapprochement of the new generation with the national culture becomes a modern pedagogical problem of our 
time, since each nation not only preserves historical traditions, but also tries to convey this to the next generations in order not to lose its national identity and identity.

\section{Conclusion}

For the formation of civic competence, it is necessary first of all to form the abilities of both students and teachers who can make decisions in different living conditions in different training situations (self-education) they can make decisions, identify problems and give solutions, as well as purposeful and responsible actions, at the same time developing creative and critical thinking.

\section{Acknowledgements}

We are thankful to the State Committee of Science of the Ministry of Education and Science of the RA, under whose financial supportthe research,in the frame of the scientific theme "18RF-003", "Model of Formation of High School Students' Civic Competency" is implemented.

\section{References}

Abramyan N., Gasparyan A., Poghosyan G. (2014). Psychological Basics of Using the Project Technology in the Environmental Education. Proceedings of The 3rd National Student Scientific Conference on The Psychology of International Participation.-Vladimir, 62-66. Galoyan S. (2004). Mental Maturity The Expression of New Quality of Education. Mankavarjutyun, 20-27

Gasparyan. A., Poghosyan G. (2016). Design Technology as a Means of Formation of Competent Citizen. Mankavarjutyun, 46-54

Key Competences For Lifelong Learning. (2006). A European Reference Framework. Official Journal Of The European Union. L 394, 30.12.

Khutorskoy A.V. (2013). Competence Approach To Learning. Scientific And Methodological Manual. A. V. Khutorskoy. M .: Publishing house "Eidos"; Publisher Institute for Human Education, 2013. - 73 p. : il. (New Standards“ Series).

Kulikova L.V., Andreeva V.V. (2012). Subculture Curriculum as an Alternative to Modern Young Subculture, The Teaching System of School: Modern Challenges/Yoshkarola

Poghosyan G., Gasparyan A., Grigoryan D., Poghosyan S. (2015). Competence Raising Through Teaching of SD Environmental Key Topics Implementing "Project Method" 2015 - Envigogika, vol.10, N 2

Zimnyaya I. A. Key Competences a New Paradigm of the Result of Modern Education/I.A. Zimnyaya // Eidos: Internet magazine. 2006. [Electronic resource]. - http://www.eidos.ru. 